\title{
INCOMPREENSÃO E SOBERBA EM MAFALDA: A COMBINAÇÃO ENTRE LINGUAGEM VERBAL E NÃO VERBAL
}

\author{
Misunderstanding and Pride in Mafalda: the combination of verbal and \\ non-verbal language
}

Diego Domingues TORRES Graduado em Letras, Centro Universitário Barão de Mauá diegodtorres83@gmail.com

Leandro Fernandes da SILVA Graduado em Letras, Centro Universitário Barão de Mauá leandrofds93@gmail.com

Paulo Eduardo de Barros VEIGA ${ }^{1}$ Pós-doutorando, Universidade de São Paulo pauloveiga@usp.br

\begin{abstract}
RESUMO: O estudo da linguagem sincrética que compõe a literatura sequencial torna-se relevante à compreensão do fenômeno poético-literário, em diálogo com a temática sociopolítica das tirinhas do quadrinista Quino, autor de Mafalda. O artigo propõe estabelecer a significação do texto, a partir da observação de homologias entre conteúdo e expressão, em vista da percepção de que o texto sincrético de Quino é, antes de predominantemente referencial, necessariamente poético. Em suma, analisa-se uma tirinha sem perder de vista o dado poético, considerando a sua estrutura como gênero textual e a sua dimensão política. PALAVRAS-CHAVE: Tirinhas; Mafalda; Poética; Significação.
\end{abstract}

\begin{abstract}
The study of the syncretic language that composes the sequential literature becomes relevant to the understanding of the poetic-literary phenomenon, in dialogue with the socio-political thematic of the comic strips by the comic artist Quino, author of Mafalda. The article proposes to establish the meaning of the text, based on the observation of homologies between content and expression plans, in view of the perception that Quino's syncretic text is, before being predominantly referential, necessarily poetic. In short, a comic strip is analyzed without losing sight of the poetic data, con-
\end{abstract}

\footnotetext{
${ }^{1}$ Pós-doutorando sob apoio da FAPESP (Processo 2018/01418-2, Fundação de Amparo à Pesquisa do Estado de São Paulo).
} 
sidering its structure as a textual genre and its political dimension. KEYWORDS: Comic strips; Mafalda; Poetic; Signification.

Partindo de uma tirinha de Quino (1932), autor de Mafalda, apresenta-se um estudo sobre a linguagem sincrética, o qual busca investigar o poético em um texto sequencial. Atento à literariedade da história em quadrinhos, toma-se essa forma não como um gênero menor, de adereço ao suporte jornalístico, mas - antes de objeto cultural - uma produção artística sincrética, que correlaciona visual e verbal. A percepção crítica, desse modo, deseja reconhecer os quadrinhos não por sua importância sociocultural, muito menos como objeto de entretenimento (porém, sem condenar a fruição de leitura), mas, principalmente, em função de sua composição poética, como invenção da linguagem, fulcro de uma obra artística. Como fundamento teórico, este estudo volta-se aos fatores e às funções de linguagem, elaborados pelo linguista Jakobson (2001). Ademais, sob inspiração da semiótica francesa, à luz de Greimas e Courtés (2008), busca-se observar as homologias entre palavra e imagem, conteúdo e expressão.

Este estudo está organizado em três etapas: a) conceituação, brevemente, do gênero "tirinha", como forma literária de expressão artística e social; b) caracterização da personagem da narrativa verbovisual, de percepção crítica, na figura de Mafalda, uma criança de expressão particular: sisuda e pragmática; e c) sugestão de leitura que descreva e analise metalinguisticamente o texto sincrético, tomado como literatura sequencial, em que se homologam palavras e imagens. Desse modo, procuram-se reconhecer aspectos artísticos do gênero e estabelecer-lhe significação temático-poética.

Além de elementos artísticos, destaca-se, das possibilidades expressivas da tirinha, o diálogo dessa forma literária com outros gêneros e outras linguagens, como o poema, a música e o cinema, uma vez que poesia, ritmo e imagem são características fundamentais do texto artístico, independentemente de seu suporte linguístico. Ou seja, tanto a poesia como a música, por exemplo, organizam-se de uma forma particular, de modo a suscitar, no leitor, uma sensação rítmica, imagética e poética. Afinal, "o ritmo não só é o elemento mais antigo e permanente da linguagem, como ainda não é difícil que seja anterior à própria fala. Em certo sentido, pode-se dizer que a linguagem nasce do ritmo ou, pelo menos, que todo ritmo implica ou prefigura uma linguagem" (PAZ, 1976, p. 11). O ritmo, dessa mesma forma, impulsiona a imagem, que constitui a poesia. Logo, por que a tirinha - ou mesmo as Histórias em Quadrinhos - haveria de estar fora desses aspectos essenciais a toda linguagem, sendo a literatura sequencial também uma manifestação potencialmente artística? 
Mafalda surge como o foco deste estudo devido, inicialmente, à sua popularidade no Brasil, por ser um "clássico" das tirinhas. No entanto, além do reconhecimento pela tradição, percebeu-se, pela leitura, uma potencialidade expressiva que colaboraria com o estudo do fenômeno poético em um gênero recente, muitas vezes ainda tratado sob jugo meramente cultural. De fato, tendo em vista a incorporação das HQ pelo mercado, há muita produção e reprodução de meros objetos de entretenimento massificado, relegando o gênero à indústria da cultura. A esse termo, em alemão, "Kulturindustrie", Ricciardi (2013, p. 57) associa os filósofos Adorno e Horkheimer, com destaque a Siegfried Kracauer:

Embora Mário de Andrade já tivesse levantado o problema, foram Adorno \& Horkheimer que cunharam a expressão inspirados num influente mestre de Adorno em seus tempos de juventude, Siegfried Kracauer (1889-1966), reconhecendo que as massas são enganadas e iludidas pela indústria da cultura.

Tendo em vista a preocupação de não confundir Kulturindustrie com Arte, e distinguir, no mundo dos quadrinhos, um produto da Cultura de uma obra artística, é importante identificar a poética do texto sincrético, proposta deste estudo. Em geral, ainda mais em se tratando de literatura sequencial, há pouca distinção do que é, de fato, arte, daquilo que é mera reprodução. No entanto, há exceções, em que resistem artistas quadrinistas, perdurando pelo espaço e tempo. Não há dúvidas de que, assim como a Música e o Cinema, entre outras artes, a disseminação do gênero quadrinho corre o risco de ficar restrita à indústria da cultura. A proposta deste estudo é buscar outra lógica, reconhecendo a poesia da linguagem sincrética, voltando-se a esse texto que, além de seu teor político, constitui-se de elementos artísticos. Trata-se, neste caso, dos textos de Quino (1932), autor de Mafalda, uma personagem infantil crítico-reflexiva que compõe uma obra verbal e visual expressivamente significativa. Assim, com base nessa ideia, em busca da percepção do texto literário visual, determinou-se a escolha de estudo pela obra do cartunista argentino.

Vale ressaltar que, no caso do texto de Mafalda, por ser escrito em língua estrangeira, o espanhol, o estudo toma como referência a sua versão traduzida para o português, já consagrada ao público brasileiro. A análise também considera, dessa forma, os elementos escritos em nosso idioma, de modo que, se alguma característica venha a se perder por conta da tradução de língua, não será feita nenhuma referência à versão espanhola ou nenhuma constatação de possíveis mudanças expressivas entre idiomas. 
Todo e qualquer elemento aqui estudado tem por base a versão traduzida e comercializada no Brasil, já consagrada. No entanto, deixa-se a sugestão de um estudo que proponha comparar texto de partida e texto de chegada em tirinhas, buscando ressaltar diferenças expressivas no plano verbal da linguagem, em outras palavras, uma poética da tradução.

\section{A HISTÓRIA EM QUADRINHOS E A TIRINHA}

É difícil determinar uma origem certa para a chamada "arte sequencial", pois se considerarmos esse termo em si, segundo Wellington Srbek (1999), é possível começar pelas pinturas rupestres feitas em cavernas na era paleolítica (cerca de 2,5 milhões de anos atrás), que passam para os hieróglifos do antigo Egito (em torno de 3500 a. C.), seguem para as pinturas feitas em vasos na Grécia Antiga (por volta do ano 530 a. C), que consistiam em figuras vermelhas num vaso preto ou em figuras pretas num vaso branco e que podiam retratar fatos do cotidiano ou contos mitológicos, muitas vezes, propondo uma narrativa por sucessão de imagens em sequência, mas sem distinção de quadros.

Já na Idade Média, segundo Maria Beatriz Rahde (2006, p. 104), as imagens começam a ganhar legendas, como no conjunto de cenas da Adoração de Cristo, extraídas do Manuscrito do Apocalipse - aproximadamente em 1230 d. C. - e na famosa xilogravura de Protat, de 1370. Nesta última, a "narrativa" é a crucificação de Cristo em que, ao pé da Cruz, um centurião romano aponta para cima e, da sua boca, desenrola-se um pergaminho com a seguinte inscrição em letras góticas: "na verdade, Este era o Filho de Deus" (Idem, ibidem).

O grande avanço que proporcionou a difusão e melhor definição dos quadrinhos foi a invenção da imprensa. Com o término da Idade Média, durante os séculos XVI e XVII, com tantas máquinas que conseguiam produzir em grandes quantidades, a informação também passou a ser um desses produtos de veiculação facilitada. Além disso, o surgimento do Iluminismo colaborou para a criação de charges satíricas com reproduções surreais, tanto de grandes personalidades como de algum problema político da época.

Entretanto, todas essas representações eram compostas por apenas um único quadro, até que, no século XVIII, surge o cartunista inglês James Gillray, que compunha suas ilustrações com dois ou mais quadros e contava com balões para a fala. O século XIX é marcado como a época de nascimento das histórias em quadrinhos, embora sua origem seja variada e dependa do conceito adotado.

Seguindo uma sequência cronológica, de acordo com Rogério de Campos 
(1999), o "primeiro" quadrinista foi o suíço Rodolphe Töpffer, que, em 1820, desenhava quadrados em sequência com a utilização de legendas, seguido, assim, por uma onda de "criadores". Em 1860, o brasileiro Angelo Agostini aparece com o personagem NhôQuim; na Alemanha, em 1865, Wilhelm Busch cria Max e Moritz; na Inglaterra, temos, em 1884, Gilbert Dalziel; nos Estados Unidos, Richard F. Outcault dá vida ao Yellow Kid; na França, em 1895, Georges Colomb (Christophe) publica a Famille Fenouillard. Inclusive, podemos citar, de certa forma, Francisco de Goya, na Espanha, no início do século XIX (Campos, 1999).

Independentemente de sua História, vale ressaltar que todos contribuíram para a consolidação dessa forma de arte. Mas é preciso frisar que os Estados Unidos tiveram um papel maior na divulgação dos quadrinhos, pela disseminação via mercado. Eles conquistavam cada vez mais espaço nos jornais estadunidenses, pois precisavam lidar com vários concorrentes pela busca de consumidores. Nessa mesma época, muitos começavam a reconhecer o poder de mercado que tinham as crianças, como alvo. Com isso, iniciaram a produção de conteúdos voltados para estes pequenos consumidores, dentre eles os quadrinhos infantis. Nem todos, no entanto, apresentavam significativos elementos artísticos.

Ainda é possível traçar um paralelo com as invenções da fotografia e cinema que também começam a surgir entre o final do século XIX e início do XX, o que carrega um aumento de tipos distintos de mídia na sociedade. Como afirma Duarte Jr. (1981), a atitude valorativa situando-se primordialmente na esfera do "sentir" é anterior à "razão". Dessa forma, é evidente que um desses efeitos da veiculação em massa é a queda da qualidade da produção. Mesmo assim, existem, hoje, boas histórias que conseguem envolver tramas complexas misturadas com várias facetas psicológicas, dramáticas e conceituais que compõem quadrinhos com qualidade.

Ainda atualmente no início do século XXI, pode-se ver até aonde é possível chegar a influência desse gênero, com o cinema que - para a produção de filmes com orçamentos gigantescos e lucros ainda maiores - parte-se de estruturas semelhantes às histórias em quadrinhos (storyboard) ou das próprias personagens popularizadas pelo gênero. História em quadrinhos e Cinema, portanto, caminham, de certa maneira, juntas, seja por seu percurso histórico, seja por sua semelhança de linguagem.

Afinal, o que são as histórias em quadrinhos? A tirinha, por exemplo, córpus deste artigo, pertence ao universo das Histórias em quadrinhos e, por essa relação próxima, a sua definição pode ajudar a apontar elementos importantes a essa linguagem no processo de análise em busca do fenômeno poético. Segundo Scott McCloud (1995, p. 09), 
histórias em quadrinhos são definidas como: “imagens pictóricas e outras justapostas em sequência deliberada destinadas a transmitir informações e/ou a produzir uma resposta no espectador". Destaca-se, também, o termo "arte sequencial", que seria a forma criada por Will Eisner (MCCLOUD, 1995, p. 05), que exige, pelo menos, duas figuras em sequência. Afinal, se considerarmos figuras isoladas ou descontextualizadas, não se identifica o gênero; porém, quando colocadas, uma na sequência da outra, em contexto ou relação, chega-se à estrutura.

Podemos imaginar, por exemplo, uma tirinha composta por dois quadrinhos: no primeiro quadrinho, um homem está com a mão em seu chapéu sobre a cabeça; no segundo, a figura permanece do mesmo jeito, com a mão no chapéu, porém há uma pequena distância entre o chapéu e a cabeça. Assim, ao passar os olhos em sequência de um desenho para o outro ou de um quadrinho ao outro, levando o olhar da esquerda para a direita, cria-se uma sensação de movimento, ou seja, de que a personagem levantou o chapéu com a mão (MCCLOUD, 1995, p. 05).

McCloud (1995, p. 07), ao aprofundar mais o conceito de "arte sequencial", amplia o termo para "arte sequencial visual". Porém, essa proposta pode se confundir com as animações. A diferença entre os dois é que, na animação, o conceito de tempo é apresentado numa única "tela", em movimento; enquanto nos quadrinhos, isso é demonstrado na passagem de um quadro para o outro, haja vista a presença de estrutura visual delimitadora, como a sarjeta.

No esforço de ser mais específico, o autor opta por "arte visual sequencial justaposta" (MCCLOUD, 1995, p. 08). No entanto, para não esbarrar numa pressuposição de que toda forma sequencial é artística, ele muda para "imagens estáticas sequenciais justapostas" (Idem, ibidem). Ainda não satisfeito, por temer uma possível aleatoriedade, altera para "imagens estáticas justapostas em sequência deliberadas" (Idem, ibidem). Dessa forma, o gênero ganha complexidade e definição. Todavia, as palavras também podem fazer parte de um quadrinho, então precisa-se incluir a possibilidade do dado verbal, resultando em "imagens pictóricas e outras justapostas em sequência deliberada" (MCCLOUD, 1995, p. 09). Por esse processo, verifica-se a definição de quadrinhos, em seu sentido complexo, assegurando a sobreposição, no plano visual, do sistema linguístico, como texto sincrético, tal qual o cinema.

De modo semelhante, pode-se conceituar o gênero tirinha. Para Barros (2005, p. 12), um texto linguístico "pode ser tanto um texto (...) oral ou escrito - uma poesia, um romance, um editorial de jornal, uma oração, um discurso político, um sermão, uma aula, uma conversa de crianças (...), como também visual, (...) uma história em quadrinhos, um 
filme, uma canção popular". Dessa forma, antes de tudo, consideram-se tanto as histórias em quadrinhos, de modo geral, quanto as tirinhas, como texto.

A "tirinha" pode ser considerada um hipergênero, pois, segundo Magalhães e Vargas (2011, p. 128), ela pertence a um campo: “denominado quadrinhos que agrega outros gêneros como, por exemplo, os cartuns, as charges, as tiras cômicas, as tiras cômicas seriadas e as tiras seriadas (...), com um ou mais quadrinhos, diálogos curtos, recursos icônico-verbais próprios (como balões, onomatopeias, metáforas visuais, figuras cinéticas etc.), personagens fixos ou não e desfecho inesperado". Dentre suas particularidades, as tirinhas possuem um aspecto humorístico e, às vezes, político, e geralmente o texto é veiculado em mídias como jornais, revistas e redes sociais.

É importante considerar, também, o termo vinheta ou quadro para a compreensão da estrutura do gênero em estudo. Segundo Mendes (1990, p. 25), a história em quadrinhos pode ser dividida em partes das quais "sua unidade básica é o quadrinho (ou vinheta), que quando apresentam-se enlaçadas encadeadamente formam a estrutura sequencial do relato". A vinheta, no ramo dos quadrinhos, é um sinônimo para o quadrinho; a menor parte na composição da história. Ademais, uma única ou mais vinhetas (se estiverem em uma sequência narrativa) compõem a história em quadrinhos.

Da mesma forma, o conceito de sarjeta é relevante à percepção da estrutura textual das HQs. Segundo o dicionário Aurélio (FERREIRA, 2010), a palavra sarjeta significa: "escoadouro nas ruas e nas praças públicas para as águas da chuva". Isto é, seria aquele pequeno espaço ou faixa um pouco mais fundo que fica entre a rua e a calçada. Nos quadrinhos, também é usado esse nome para referir ao espaço que fica entre dois quadros, e, segundo McCloud (1995, p. 66-67), serve para quando: “... a imaginação humana capta duas imagens distintas e as transforma em uma única ideia. Nada é visto entre os dois quadros, mas a experiência indica que deve ter alguma coisa lá”. Em resumo, a sarjeta ajuda na noção de que, entre uma figura e outra, o tempo ou o espaço sofreram alguma mudança. Assim, é importante considerar esse recurso na percepção da estrutura poética da linguagem sincrética.

Para o leitor, a sarjeta sinaliza, pois, mudanças no tempo ou espaço entre os quadros e, todavia, não é a única indicadora, pois a moldura que existe nos quadros ajuda a entender o que acontece dentro deles. Para ser mais específico, segundo McCloud (1995, p. 99), o quadro não deixa de ser um tipo de indicador geral a respeito da organização do tempo e do espaço. Assim, "a duração do tempo e as dimensões do espaço são definidas mais pelo conteúdo do quadro do que pelo quadro em si". Para isso, os quadrinistas fazem o uso de algumas técnicas. Quando há indicação da passagem de tempo entre os quadros, 
pode-se colocar um termo, chamado por McCloud, "quadro de pausa", que, colocado entres dois quadros de ações, indica o que um personagem pensava, ou que um carro andava, ou o sol nascia, enfim, ele serve para ajudar o leitor a perceber um período.

Ainda há outras possibilidades expressivas para sugerir a passagem do tempo. Para esse efeito, por exemplo, é possível desenhar um número maior de quadros de pausa entre os quadros de ação. Outro recurso é aumentar o tamanho do quadrado, transformando-o em um retângulo, para provocar visualmente a sensação de maior passagem de tempo, quando se compara com os demais. Em relação a esses dados de efeito temporal, é importante analisá-los sempre em relação a um contexto, isto é, sem perder de vista a percepção do todo textual, considerando imagem e palavra.

\section{EM BUSCA DO FENÔMENO POÉTICO NO TEXTO SINCRÉTICO}

Para Jakobson (2005, p. 122), “a linguagem deve ser estudada em toda sua variedade de suas funções". O linguista afirma da concomitância dos fatores e respectivas funções na comunicação. Porém, ressalta o linguista de que uma função se sobressai. Por todo processo de comunicação, seja verbal, seja visual, há o remetente que envia uma mensagem ao destinatário. A mensagem necessita de um contexto ou referencial (que, nesse caso, pode-se sugerir a crítica apresentada pelas tirinhas), que seja compreensível ao destinatário de maneira verbal ou não verbal (embora o autor apresente de maneira verbal ou suscetível de verbalização); um código, que seja presente no repertório tanto do emissor quanto do receptor (a exemplo, nossa língua materna) e, por fim, um contato, que faça com que o canal de comunicação permaneça aberto (a tirinha).

A partir da percepção das funções linguísticas, a presença da função emotiva ou expressiva é recorrente nas tirinhas, com o apelo de chamar a atenção do destinatário pelo remetente mediante uma linguagem subjetiva (em muitos casos, trazendo uma crítica velada). Outra função, a conativa, voltada ao destinatário, tem por finalidade remeter-lhe, seja com o uso do vocativo, seja uma linguagem imperativa, que podem, assim, prender a atenção daquele que recebe a mensagem.

Tendo em vista a proposta do linguista, nota-se, nas tirinhas da Mafalda, um pendor à função poética, que, ao contrário do que o nome pode sugerir, o próprio autor afirma que não se trata apenas da poesia, mas de diferentes gêneros, de distintas semióticas. Assim, diz:

a Poética trata fundamentalmente do problema: Que é que faz de uma mensagem verbal uma obra de arte? Sendo o objeto principal da 
Poética as differentia specifica entre a arte verbal e as outras artes e espécies de condutas verbais, cabe-lhe um lugar de preeminência nos estudos literários (JAKOBSON, 2005, p. 118).

Passa-se, com isso, a tentar perceber as tirinhas em sua centralidade poética, como texto artístico, capaz de expressar uma narrativa curta, de modo conciso e filosófico, tal qual o poema.

\section{BREVE COMENTÁRIO SOBRE MAFALDA}

Em 29 de setembro de 1964, tirinhas de Quino foram publicadas oficialmente na revista "Primera Plana", que divulgava textos com teor político, cheios de metáforas e de ironia (SILVA, 2015). A protagonista, Mafalda, é uma menina de sete anos que vive em Buenos Aires. Sua peculiaridade é odiar sopa e ter uma alta sensibilidade críticopolítica. Além disso, ela nunca se conforma com as injustiças sociais, mas acredita em um futuro melhor. Em relação ao nome "Mafalda", Quino inspirou-se em uma personagem homônima de um filme de David Viñas, Dar la cara (1962). Também, na época da criação do nome, a Agens Publicidad pedia que a personagem começasse com a letra "M" (SILVA, 2015, p. 35).

Os pais da menina aparecem no mesmo ano, resultado também daquele primeiro esboço. A mãe, uma dona de casa, chama-se Raquel; do pai, não se cita o nome, apenas infere-se que trabalha em um escritório; ambos são adultos na faixa dos 40 anos, de classe média, sempre passivos nas histórias. Em 1965, surge Felipe, um amigo de Mafalda, inspirado em um conhecido de Quino que também tinha dentes grandes. De personalidade sonhadora, mas, ao mesmo tempo, tímido e preguiçoso, adora histórias de aventura. No mesmo ano, mais um personagem integra a turma, Manolito, com um perfil de garoto bruto, ambicioso e materialista; em seu íntimo, tem um grande coração. Gosta de Rockefeller e odeia os hippies (QUINO, 2007).

Também em 1965, é criada Susanita, típica fofoqueira, briguenta e egoísta, não gosta da Mafalda, nem de pobres e quer se casar com um marido rico. Já Miguelito aparece em 1966 muito sonhador e egoísta, pois quer ser notado por todos, apesar da pouca idade. Guille é o irmão mais novo de Mafalda, estréia nos quadrinhos em 1968, ainda na idade das descobertas, de índole muito terna; é bastante curioso, adora rabiscar as paredes e chupar chupeta. Por fim, Liberdade aparece somente em 1970, uma menina de esquerda que adora os protestos e as lutas sociais; vem de família simples com pais que trabalham muito (SILVA, 2015). 
O universo Mafalda pode ser lido considerando a ótica textual e visual, com o que cada uma apresenta em seus elementos relevantes, como a expressão das personagens, o cenário, a disparidade entre os adultos e as crianças. Suas cabeças são desproporcionais ao corpo, em contraste entre o corpo de criança e a cabeça de adultos.

É fundamental a uma leitura atenta perceber o plano visual, com destaque aos aspectos psicoexpressivos das personagens, em paralelo ao seu ambiente, à condição social e ao contexto que, por mais datada que seja a personagem, possui estereótipo muito atual. Mafalda, por exemplo, a protagonista, vai na contramão de sua faixa etária, pois possui uma expressão sisuda e pragmática. Enquanto ela é desproporcional, quanto à cabeça e ao corpo, sugerindo uma criança em processo de crescimento, os adultos aparecem por inteiro, de modo proporcional. Já o espaço é mais relevante quando notável e detalhado, atribuindo mais sentido ao contexto. Por exemplo, muitas vezes, a transição entre os quadros raramente se alterna, o que pode ser pertinente ao processo de leitura, reduzindo importância ao espaço, para que se destaquem outros elementos.

A seguir, apresenta-se a análise de uma tirinha em que os quadros são do mesmo tamanho, o que, do ponto de vista da expressão visual, sugere uma passagem de tempo curta, como se contassem poucos segundos, e um espaço pouco significativo, que não se altera.

\section{MAFALDA E O RÁDIO: INCOMPREENSÃO E SOBERBA SOCIAL}

Escolheu-se uma tirinha, retirada da coletânea de tirinhas da Mafalda (2007), que fosse mais expressiva em relação à composição poética, com destaque aos planos verbal e visual. Procurou-se, inicialmente a partir de uma análise gramatical e semântica, correlacionar o tema do texto à organização das figuras e das formas visuais. Vale observar a criticidade de Mafalda, na figura da criança, que deveria ser alheia aos problemas sociais; porém, ela tece uma crítica político-social fruto de uma experiência sagaz sobre o mundo. Mafalda, assim, é mais realista, pois tem um olhar crítico e irônico e apresenta um discurso verbal mais elaborado. Desse modo, analisa-se uma tirinha de Quino em que a protagonista Mafalda interage com um rádio como se tecesse um diálogo. Procurou-se observar a relação entre o tema central, qual seja, a oposição compreensão e incompreensão, e a disposição figurativa do texto, entre um rádio e uma menina. Além disso, a partir do texto verbal, mais especificamente, da comparação metafórica entre a vida e um rio, a protagonista denuncia a soberba social, em que todas as pessoas consideram-se capazes de julgar a vida alheia. 
A tirinha utilizada para estudo foi retirada da edição Toda a Mafalda, de Quino (2007), traduzida por Andréa Stahel et al., e publicada pela editora Martins Fontes. Na página 287 do livro, encontram-se cinco tirinhas em preto e branco. A tirinha em análise é a quarta, de cima para baixo, a única composta por três quadrinhos. Ela pode ser assim descrita:

No primeiro quadrinho, Mafalda encontra-se à direita, deitada com os joelhos dobrados, em posição relaxada. Usa sapatos típicos de sua personagem e um vestido com estampa de estrelas, desenhadas como asteriscos. Reforça-se que não há cores. Ela ouve o rádio que se encontra à esquerda, retangular, com antena levantada. Há um único balão em que o locutor do rádio diz: “Alguma vez, caros amiguinhos, vocês já se perguntaram o que é a vida?". Destaca-se que o balão de fala que "sai" do rádio tem a sua base em formato de raio ou faísca elétrica, não se tratando, portanto, de um balão de fala padrão. Em relação ao espaço, não há nada relevante, nenhum elemento significativo, o que põe em destaque a figura do rádio e a da Mafalda, ambos no chão.

No segundo quadrinho, Mafalda permanece na mesma posição do quadrinho anterior, relaxada, deitada no chão com os joelhos ainda dobrados. O rádio permanece também na mesma posição, à esquerda de Mafalda. A principal diferença é a fala do locutor do rádio, contida em balão faísca elétrica, que se altera, continuando a narrativa: "Pois bem, meus queridos, a vida é como um rio".

No terceiro quadrinho, o rádio permanece à esquerda, já sem fala. Mafalda assume a voz dizendo: "É, o problema é que todo o mundo acha que entende de hidráulica, não é?". Nota-se que o corpo de Mafalda já não se apresenta relaxado, mas parcialmente levantado, como se ela quisesse conversar com o rádio. A sua cabeça está erguida e somente um joelho está dobrado, estando o outro esticado. O balão é padrão, típico de fala, arredondado. A expressão do rosto de Mafalda é de decepção, estando a boca levemente inclinada para baixo. O olhar volta-se ao rádio, que está no chão, estando as sobrancelhas tensionadas. Perto do ombro direito e da parte de trás da cabeça, há pontos formando pequenas curvas que sugerem movimento parcial do corpo.

Procedendo, mais especificamente, à análise, pode-se observar, logo na primeira vinheta, no plano discursivo, mais concreto e figural, a personagem Mafalda - protagonista recorrente da obra de Quino - deitada no chão, em silêncio. Ao seu lado, há um rádio ligado, dado perceptível porque, dele, sai um balão de fala, possivelmente de um locutor de programa infantil, que faz uma pergunta aos seus pequenos ouvintes ("amiguinhos").

Vale observar a distinção visual que se estabelece entre o balão da fala do rádio, de contorno mais retilíneo ou menos suave e circular, sugerindo, pois, uma voz mais 
estridente, que venha de um aparelho eletrônico, e que, segundo Eguti (2001), recebe o nome de balão-faíscas elétricas. Essa forma encontra-se em oposição ao balão da fala humana, de linhas mais suaves, que, segundo Paulo Ramos (2009, p. 37), seria: “...o mais comum e expressivamente o mais neutro; possui contorno com traçado contínuo, reto ou curvilíneo; também é conhecido como balão de fala". Esse tipo de balão acaba por ser o mais comum, utilizado para representar a fala de um personagem em uma situação normal. A contraposição dos balões a seguir reforça visualmente a distinção, carregando de sentido os dados visuais, em relação ao texto verbal. Essa oposição visual, portanto, é expressiva porque é capaz de suscitar uma impressão acústica no leitor: a de que a voz do rádio seja mais artificial e estridente (como nos velhos rádios, de tecnologia analógica), em oposição à voz mais orgânica e natural de Mafalda.

Ainda no primeiro quadro, nota-se que o locutor interpela o ouvinte infanto-juvenil com a expressão "caros amiguinhos", importante vocativo entre vírgulas, que indica ao leitor o público do programa: crianças e adolescentes. O éthos desse locutor, que se infere pelo discurso, pode ser caracterizado pela afetividade, embora ainda formal. O sintagma "caros amiguinhos" apresenta um adjetivo - "caros" - de teor menos íntimo, embora respeitoso, seguido do substantivo "amiguinhos", no diminutivo e plural, que sugere um efeito, suscitado pelo contexto visual, de proximidade. Há, portanto, um diálogo entre um adulto e um público composto por crianças e adolescentes.

Na segunda vinheta, o locutor profere a expressão "meus queridos", aproximandose um pouco mais de seu ouvinte, efeito reforçado pelo pronome possessivo "meus", a fim de assegurar o diálogo com o seu público, chamando-o constantemente, como recurso fático, que, segundo Jakobson (2001), pode ter a função, dentre outras, de prolongar a comunicação, atrair a atenção do interlocutor ou confirmar sua atenção continuada. Contudo, como o rádio somente permite que a mensagem chegue a seu ouvinte, sem que ele possa retornar uma resposta, o locutor do programa não tem como saber se sua fala agrada ou desagrada. Assim faz-se o uso do termo "meus queridos" propositalmente como que para atrair e manter a atenção do público, de modo a estabelecer um contato de nível mais informal e a tornar o diálogo mais agradável para as pessoas escutarem e manterem a audiência do programa. Ou seja, apesar de formal, o locutor demonstra uma preocupação de transparecer, em seu discurso, afeto e proximidade.

Na primeira e na segunda vinheta, a posição de Mafalda, estando deitada, sugere também essa aproximação, mediante sua descontração. Não se trata mais de uma fala de cunho político, mas de cunho filosófico ou metafísico (“o que é a vida?"), que resulte em uma crítica social ("todo o mundo acha") contra a presunção generalizada. 
Ademais, pode-se destacar, ainda em um plano gramatical do texto verbal, isto é, em seu nível linguístico - em diálogo com a disposição das imagens, como o rádio próximo de Mafalda - um elemento sintático que ajuda o locutor a criar esse efeito de intimidade: o hipérbato. Nota-se, na pergunta, uma escolha da ordem dos termos sintáticos, que não aparecem de maneira canônica, sob efeito da inversão. Assim, se a oração fosse colocada em outra disposição frasal, poderíamos ter, assegurada a clareza da frase, a seguinte sentença: "vocês já se perguntaram o que é a vida, caros amiguinhos?" Porém, ocorre uma inversão sintática proposital, com intenção de colaborar para que discurso do locutor fique mais apelativo e próximo, assim como o vocativo está mais próximo do início da frase. O uso deste recurso enfoca a mensagem, no sentido jakobsoniano - isto é, o autor, ao escrever este discurso, reorganiza as palavras de modo a trazer um efeito de sentido, ou um significado diferente. Mesmo que sejam usadas as mesmas palavras, a sua leitura tem como objetivo provocar uma reação diferente em seu receptor. Dessa forma, nota-se a figura de construção denominada hipérbato que aproxima o locutor do ouvinte, chamando-lhe a atenção, com intuito retórico.

Em relação à análise visual de quadrinhos, é importante perceber os expedientes expressivos suscitados pela "sarjeta" (MCCLOUD, 1995). No caso, a sarjeta é significamente estreita, encurtando a marca de tempo entre as vinhetas e dinamizando o diálogo. Sua função é separar a fala do locutor entre a pergunta feita no quadro anterior e a resposta no seguinte. Essa ideia é reforçada pelos elementos pictóricos que permanecem inalterados, entre as duas primeiras vinhetas. Ou seja, tanto o rádio quanto a menina continuam sem qualquer mudança visual, mantendo-se, inclusive, o mesmo fundo, garantindo maior destaque ao texto verbal. $\mathrm{O}$ único elemento que permite afirmar a passagem de tempo ou a impressão de narrativa, afinal, são as falas e os balões de texto. Neles, o locutor ainda continua a comunicar-se com o ouvinte, por meio dos vocativos, alterando a mensagem e a forma dos balões. $\mathrm{O}$ expediente estético da sarjeta, portanto, tem um forte vínculo semântico com a sequência visual e narrativa, pois confere ao texto dinamicidade do diálogo.

Outra característica visual que corrobora o mesmo efeito que suscita a sarjeta é o contorno dos quadros. Eles não sofrem nenhuma alteração em seus tamanhos, tampouco seja necessário acrescentar um quarto quadro para prolongar a duração da leitura (MCCLOUD, 1995). Seguindo essa ideia, o rádio não apresenta qualquer sinal de alteração, tanto textual quanto pictórico; Mafalda, porém, demonstra uma reação, observada tanto por sua posição mais ereta (ergue a cabeça) e, também, por seu rosto, que traz uma expressão inconformada diante da presunção ou soberba social. A mudança de 
estado corporal gera, no plano visual, uma micronarrativa. Mafalda sai da passividade para a inconformidade. A oposição horizontal e vertical, na imagem, corrobora essa alteração de estado: a de um ouvinte passivo para a contestação crítica contra a presunção social.

O sentimento crítico de Mafalda ajuda a reforçar o texto verbal trazido em sua fala, na qual tanto o locutor quanto a menina valem-se do uso de metáfora, desdobrando-a. Isto é, a palavra "hidráulica" é o desdobramento da metáfora primeira, o rio, no mesmo campo semântica da água. Sua crítica está na segunda metáfora, desdobrada, a partir da primeira feita pelo locutor. Com o termo "hidráulica", portanto, a menina denuncia a soberba de uma sociedade que se considera sempre apta a julgar.

Assim como no caso do hipérbato utilizado pelo autor na segunda vinheta, a metáfora aqui também tem efeito poético, que, nesse caso, faz mediante uma mudança no significado das palavras. Ou seja, ele se utiliza das palavras "rio" e "hidráulica" para comparar o elemento água à vida.

Mais especificamente no plano verbal, a personagem utiliza a palavra "é" três vezes, no mesmo balão, reiteração que reforça o tom crítico, questionador. Enquanto o rádio traz uma fala mais formal e lírica, Mafalda utiliza-se de uma linguagem mais informal, enfática e crítica. Desse modo, expedientes expressivos visuais e verbais relacionam-se em solidariedade para construir a mensagem central do quadrinho, um diálogo artificial entre uma menina e um rádio cuja conclusão seja uma denúncia da presunção ou soberba social.

A construção da tirinha, em suma, utiliza-se dos elementos pictóricos com o objetivo de reforçar os textos verbais, na qual o autor, mediante o emprego de figuras de linguagem, transforma o significado das palavras de maneira intencional, que, somados, ajudam a passar um preceito para o leitor, neste caso, uma crítica ao modo como as pessoas se intrometem na vida das outras.

Em resumo, Mafalda é um exemplo expressivo do gênero tirinha, tendo em vista a elaboração do texto, a partir de homologias ou combinações entre conteúdo e expressão. Além disso, o corpus apresenta a verossimilhança com a sociedade contemporânea, tendo em vista a criticidade de uma "criança" sobre o aspecto mais social do mundo, como faz Mafalda.

Poderia ser um adulto a fazer as críticas ou a travar diálogos reflexivos do nível que apresenta a tirinha; mas será que haveria o mesmo choque ou a mesma repercussão do que pelo olhar de uma criança? Todos esses dados tornam-se significativos na concepção do texto metafórico, antes de tudo, poeticamente expressivo.

A teoria de Jakobson sobre a função poética, bem como os recursos utilizados 
nos quadrinhos, apontados por McCloud (1995), por exemplo, auxiliaram no processo de análise da tirinha, em busca do fenômeno poético, com vistas à homologia entre conteúdo e expressão. Somados todos os elementos, sejam visuais, sejam verbais, estabeleceramse significados no texto sincrético, construído de uma forma única, a do artista, que reinventa a linguagem. O principal resultado é perceber a tirinha como um gênero, de fato, expressivo, quer em âmbito sociopolítico, quer - ainda mais em Quino - necessariamente poético-literário. 


\section{REFERÊNCIAS:}

BARROS, D. L. Teoria Semiótica do Texto. 4. ed. São Paulo: Ática, 2005.

CAMPOS, R. Fealdade de Fabiano Gorila. Marcelo Gaú. São Paulo: Ed. Conrad, 1999.

DUARTE JR., J. F. Fundamentos Estéticos da Educação. São Paulo: Cortez, 1985.

EGUTI, C. A. A representatividade da oralidade nas histórias em quadrinhos. São Paulo, 2001. 183 f. Dissertação (Mestrado em Filologia e Língua Portuguesa) - Faculdade de Filosofia, Letras e Ciências Humanas, Universidade de São Paulo, 2001.

FERREIRA, A. B. de H. Dicionário Aurélio da língua portuguesa. 5. ed. Curitiba: Positivo, 2010.

FIORIN, J. L. Elementos de análise do discurso. 13. ed. São Paulo: Contexto, 2005.

GREIMAS, A. J.; COURTÉS, J. Dicionário de Semiótica. Trad. Alceu Dias Lima et al. São Paulo: Contexto, 2008.

JAKOBSON, R. Linguística e comunicação. 18a ed. Tradução de Izidoro Blikstein e José Paulo Paes. São Paulo: Cultrix, 2001.

MAGALHÃES, L. M.; VARGAS, S. L. O gênero tirinhas: uma proposta de sequência didática. Disponível em: <http://www.ufjf..br/revistaedufoco/files/2012/08/Texto-05. pdf>. Acesso em: 27 out. 2018.

MCCLOUD, S. Desvendando os quadrinhos. Tradução de Helcio de Carvalho e Marisa do Nascimento Paro. São Paulo: Makron Books, 1995.

MENDES, M. R. S. El Papel Educativo de los Comics Infantiles: (Análisis de los Estereotipos Sexuales), 1990. Tese de Doutorado, Facultad de Ciencias de la Información da Universidad Autónoma de Barcelona, Barcelona, 1990.

PAZ, O. Signos em rotação. São Paulo: Perspectiva, 1976.

PESSOA, A. R. Histórias em Quadrinhos: Um meio Intermidiático. Disponível em: $<$ http://www.bocc.ubi.pt/pag/pessoa-alberto-historias-em-quadradinhos.pdf $>$. Acesso em: 27 out. 2018.

QUINO. Mafalda. Disponível em: <http://www.quino.com.ar/>. Acesso em: 27 out. 2018. 
QUINO. Toda a Mafalda. Tradução de Andréa Stahel M. da Silva et al. São Paulo: Martins Fontes, 2007.

RAHDE, M. B. Origens e Evolução das Histórias em Quadrinhos. Disponível em: <http:// revistaseletronicas.pucrs.br/ojs/index.php/revistafamecos/article/viewFile/2954/2238>. Acesso em: 27 out. 2018.

RAMOS, P. A leitura dos quadrinhos. São Paulo: Contexto, 2009.

RICCIARDI, R. R.; ZAPRONHA, E. Quatro ensaios sobre música e filosofia. Ribeirão Preto: Editora Coruja, 2013.

SILVA, B. Z. As tiras de Mafalda no Brasil: tradutores e traduções. 2015. Dissertação (Mestrado em Letras). Departamento de Letras Modernas da Faculdade de Filosofia, Letras e Ciências Humanas da Universidade de São Paulo, 2015.

SRBEK, W. A origem histórica dos quadrinhos (de hoje). Disponível em: <http://www. portcom.intercom.org.br/pdfs/4211ee202ca92842d8b5334cb7fe6abd.PDF $>$. Acesso em: 27 out. 2018. 